\title{
The Energy Production and Efficiency Treatment of ML-MFC Using High Organic Content Wastewater
}

\author{
Aris Mukimin* \\ Center of Industrial Pollution Prevention Technology, Semarang - Indonesia
}

\begin{abstract}
Microbial fuel cell (MFC) is a technology that is not only able to produce energy but also treats wastewater. The membraneless microbial fuel cell (ML-MFC) system was developed to avoid the use of membranes that are prone to clogging and are less applicable. The reactor was made and arranged in two chambers connected by pipes and the fluid flow rate is set using a peristaltic pump. Three anodes (carbon cloth) were paired with a carbon-Pt cathode GDL (Gas Diffusion Layer) type. The reactor was applied to wastewater taken from the industrial WWTP unit at the point before and after UASB. ML-MFC reactors can produce currents of $0.2 \mathrm{~mA}$ (before UASB) and $0.25 \mathrm{~mA}$ (after UASB). Current production is strongly influenced by the flow rate and characteristics of wastewater. Increased flow rates and complex character of wastewater will reduce current production. The electric power produced is 0.035 mwatt for wastewater before UASB and 0.086 mwatt after UASB with a COD removal is close to the same, which is $21 \%$ at a flow rate of $11 \mathrm{~L} / \mathrm{min}^{1}$
\end{abstract}

Keywords: ML-MFC; Renewble energy; Carbon cloth GDL; wastewater

\section{Introduction}

Fuel Cell (FC) is one of the technologies that play a role in providing alternative energy that is increasingly in demand as fossil energy sources are increasingly depleted [1-2]. Two types of FC that have been known and developed include Chemical Fuel Cell (CFC) and Microbial Fuel Cell (MFC). This last FC type is more promising because it does not require chemicals so it is cheap in operation and has a positive impact on the environment [3]. MFC technology besides being able to produce electrical energy also functions as a waste treatment unit through the degradation of organic compounds into carbon dioxide $\left(\mathrm{CO}_{2}\right)$, hydrogen ions $\left(\mathrm{H}^{+}\right)$, and electrons (e).

The most of all Microbial Fuel Cells are arranged in a double chamber model, where the anode chamber is separated from the cathode [4-6]. This cell model uses a membrane as a

\footnotetext{
*Corresponding author:arismukimin@gmail.com
} 
separator material that will get through cation or anion species. The point of weakness of this cell type lies in clogging on the membrane surface, ion transfer velocity, and investment cost. Replacement of membrane materials with relatively inexpensive materials such as glass wool [2], ceramics, metals oxide, asbestos [7] has been carried out. Ion selectivity and velocity transfer are still small compared to membranes so that energy production is low. The use of membranes also causes the application to be less flexible so that the applicators of this technology are less interested.

The design of the MFC reactor without a separator material called the membraneless microbial fuel cell became the most applicable model to be developed [8-10]. The chamber unit is made singly with the anode at the bottom and the cathode at the top. The reactor configuration is simple and easy to operate [11-12]. Air supply around the cathode makes it difficult to achieve zero oxygen around the anode, oxidation reactions become disrupted and another process that reduces electron formation. The efficiency of electricity production is low so it is not in line with the MFC technology target as an alternative energy source.

Membraneless microbial fuel cells by removing oxygen from the anode chamber were carried out in this study. The anode and cathode chambers are made separate by only connecting them through three canals. The fluid flow is regulated upstream so that it helps transfer hydrogen cations from the anode to the cathode and inhibits the movement of oxygen to the anode. Performance cell investigations for flow rates and types of wastewater with electricity production performance and COD reduction as indicators.

\section{Methods}

\subsection{Materials}

Wastewater as a source of organic material is obtained from the honey industry in Wonogiri. Microbacteria were produced from anaerobic sludge filtration seawage mixed with a buffer solution. $\mathrm{KCl}$ (Merck) $\mathrm{NH}_{4} \mathrm{Cl}$ (Merck), $\mathrm{NaH}_{2} \mathrm{PO}_{4}$ (Merck), $\mathrm{NaHCO}_{3}$ (Merck), $\mathrm{CH}_{3} \mathrm{COONa}$ (Merck) Ferric oxide (domestic trade), all are pro analysis except Ferri oxide. The anode material was made from MDL carbon cloth, while the cathode from the $20 \% \mathrm{GDL}$ Pt/C was ordered from FuelCellStore 1902 Pinon Station U.S. GWINSTK GDM-396 with the Ver1.00 program interface and voltage with HANTEK 365D as an electrical data recorder that was measured through current and voltage. ML-MFC reactor configuration as shown in Figure 1. 


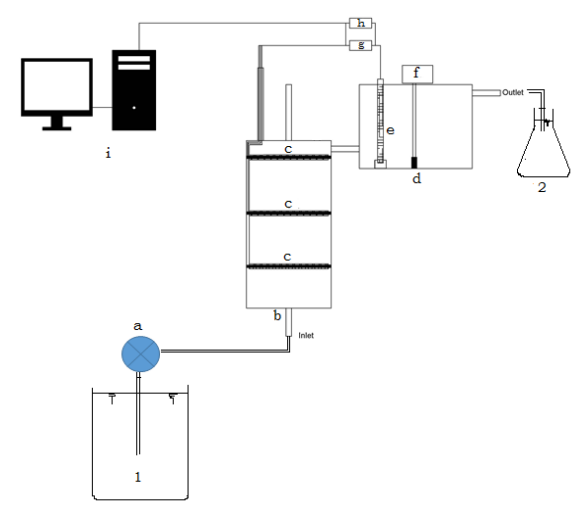

Fig 1. ML-MFC up-flow reactor consists of (1) feeding chamber, (2) result collected chamber, (a) peristaltic pump, (b) anode chamber, (c) MPL carbon cloth anode, (d) cathode chamber, (e) Pt-C cathode, (f) aerator, (g) resistor, (h) data logger, dan (i) PC

\subsection{Procedure}

Feed the biomass filtrate (micro bacteria) into the ML-MFC reactor using a peristaltic pump with a flow rate of $8 \mathrm{~mL} / \mathrm{min} .4 \mathrm{~L}$ of nutrient made from $0.4 \mathrm{KCl} ; 0.8 \mathrm{~g} \mathrm{NH} 4 \mathrm{Cl} ; 2.4 \mathrm{~g}$ $\mathrm{NaH}_{2} \mathrm{PO}_{4} ; 40 \mathrm{~mL}$ trace element; $8 \mathrm{~g}$ of $\mathrm{NaHCO}_{3}, 60 \mathrm{~g}$ of Ferric oxide and $10.8 \mathrm{~g}$ of $\mathrm{CH}_{3} \mathrm{COONa}$ are then inputted at a rate of $11 \mathrm{~mL} / \mathrm{min}$ and stream nitrogen gas to ensure anaerobic conditions. Set the DC potential to the anode and cathode poles with a voltage of $0.3 \mathrm{~V}$. Circulate for 2 days in the anode chamber. After the biofilm grows at the anode, the wastewater of the honey industry (before UASB) was pumped to the anode chamber and then the cathode compartment was aerated. Set the flow rate of wastewater around $8 \mathrm{~mL} / \mathrm{min}$, record and save the current data generated during the process using GWINSTK GDM-396 with the Ver1.00 program interface and voltage with HANTEK 365D. Take the wastewater before and after the reactor process to analyze the COD content. The performance of the reactor to produce an optimum power output so the variable of flow rate for 9,10 , and 11 $\mathrm{mL} / \mathrm{min}$ was be done. Replace the type of waste with wastewater after UASB and acetate.

\section{Result and discussion}

\subsection{Current Production as fungsion flow rate}

The Ml-MFC reactor that works continuously flow has produced currents with a range of values 0.034 to $0.228 \mathrm{~mA}$. The amount of current generated is strongly influenced by the flow rate in Figure 2. 


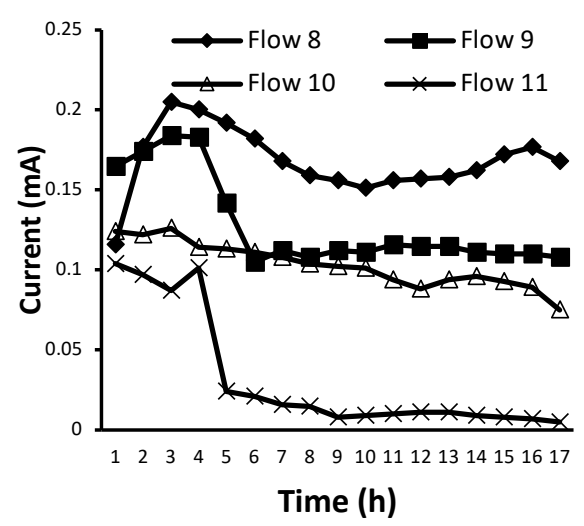

Fig 2. The current production of the input UASB wastewater for a variety of flow rate in processing time.

Current production tends to decrease with an increase in flow rate. The largest current production is generated for flow $8 \mathrm{~mL} / \mathrm{min}$ and the smallest for $11 \mathrm{~mL} / \mathrm{min}$. This tendency is predominantly influenced by electron production by microbes. At a flow rate of $8 \mathrm{~mL} / \mathrm{min}$, the quantity of pollutant oxidation is relatively highest compared to other flow rates. The high oxidation quantity will correlate directly with the number of electrons produced so as to produce a large current. The reverse condition is shown for a flow rate of $11 \mathrm{~mL} / \mathrm{min}$, where the current production drops to near zero. A large flow rate also means that short processing time will make the oxidation potential of pollutants smaller. The fact of this result is also supported by the character of wastewater pollutants, by choosing the source of wastewater from the tub before the UASB, in addition to the large organic burden also by the complexity of the pollutant structure. Wastewater before UASB has a large pollutant structure and tends to be low in solubility, making it difficult for microbes to degrade

A different phenomenon is shown for real wastewater taken after UASB. Current response data from this wastewater source is presented in Figure 3.

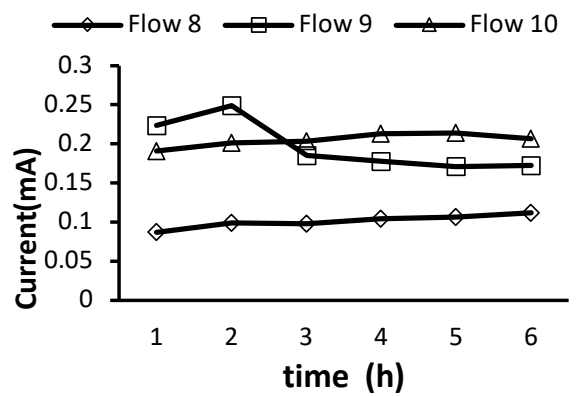

Fig 3. The current production of the output UASB wastewater for a variety of flow rate in processing time

The current response tends to increase with increasing flow rate, where the highest value is obtained for a flow of $10 \mathrm{~mL} / \mathrm{min}$. This trend data indicates that pollutant wastewater is already in a simpler compound condition so that the oxidation process that produces electrons will take place quickly. This type of wastewater will make charge transfer a determinant of 
the production of current generated. This clarification reinforcement was confirmed by COD data from each waste as contained in Table 1

\subsection{Energy Production for Variety Wastewater}

Current and voltage data generated during the ML-MFC reactor application can be calculated the electric power generated. Figure 4 has shown the electric power product produced from the ML-MFC reactor for several types of wastewater with a variety of flow rates. The electric power that can be produced by the reactor is in the range of $0.018 \mathrm{~mW}$ to $0.086 \mathrm{~mW}$. Wastewater from acetate (synthetic) produces the lowest electric power, while wastewater after UASB has the highest production. This production trend is strongly controlled by the quantity of organic matter as a source of carbon and the ease of oxidation by microbes to form electrons.

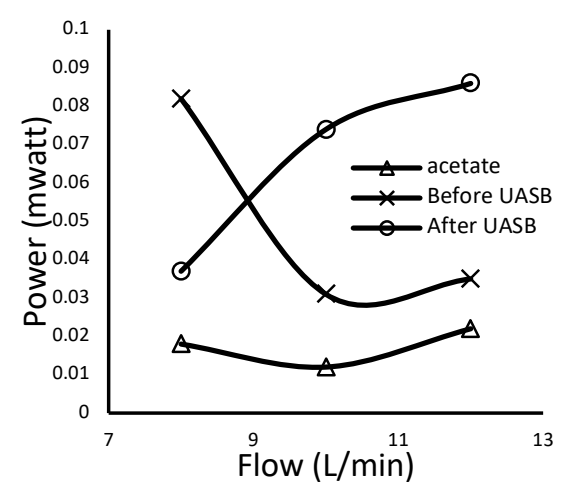

Fig 4. Power production for acetate, before and after UASB wastewater

Wastewater after UASB is a type of waste that has a large carbon content and has a relatively simple structure compared to wastewater before UASB. This condition causes electricity production from wastewater after UASB to be higher.

The value of electric power production does not match the above trend for low flow rate operating conditions. Figure 4, the highest value of electric power production is obtained from wastewater before UASB with the smallest flow rate, which is 8 . This tendency arises because the character of wastewater before UASB which is rich in organic and has a more complex structure so that the production of electrons will be large if the chance of processing time is longer. Low flow rate (flow 8) will provide contact time between organic pollutants and larger microbes so that the electron production will increase. At a low flow rate (flow 8), the power produced tends to be the lowest

\subsection{The Performance of COD Removal}

ML-MFC reactor in addition to functioning to produce electricity also has a role to reduce the pollutants in the wastewater. This reactor behavior will make at once as a wastewater treatment unit. Figure 5 shows the reduction of COD for the two types of wastewater that are fed into the reactor 


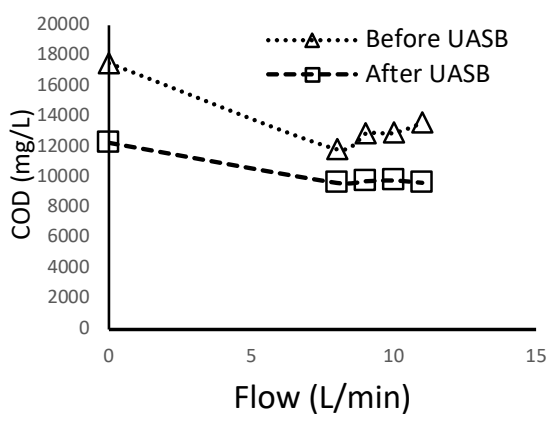

Fig 5. The reduction COD trend for wastewater before and after UASB in some flow rate

Two examples of wastewater were taken on before and after the UASB unit. Based on the results in Figure 5, the COD reduction of wastewater after UASB is greater than before UASB. This tendency is influenced by the character of wastewater, where after UASB pollutants will be simpler so that the oxidation or degradation process will be easier or faster. Conversely, the character of wastewater before a more complex UASB will require a longer degradation time so that the reduction efficiency is smaller.

The phenomenon of wastewater pollutant character that influences the treatment efficiency is strengthened by the data series of flow rate variations. Based on the data in Figure 5, for wastewater before the UASB, it is obvious that the decrease in COD has weakened by an increase in flow rate. The greater the flow rate is conditioned the smaller the COD decrease, it indicates that the number of pollutants undergoing oxidation decreases due to faster processing time, while the pollutant character is more complex. Different facts are shown by wastewater after UASB, the increase in flow rate does not significantly influence the decrease in COD. The decrease in COD was relatively the same for each increase in flow rates of $8,9,10$, and $11 \mathrm{~mL} / \mathrm{min}$. This behavior informs that the structure of pollutants is simpler so reducing the duration of the oxidation process does not have an impact on the efficiency of COD reduction

\subsection{The Convertion of COD Removal to Energy Product}

Electrical energy in the microbial fuel cell system is formed through the degradation of organic carbon by microorganisms into $\mathrm{CO}_{2}, \mathrm{H}^{+}$, and electrons. This degradation mechanism has taken place in a membrane-less microbial fuel cell reactor in a continuous flow as shown in Table 1 . A large quantity of COD degradation $(5659 \mathrm{mg} / \mathrm{L})$ will increase energy production (0.082 watts), whereas a lower decrease $(4591 \mathrm{mg} / \mathrm{L})$ will produce less energy (0.031 watts).

Table 1. COD removal vs energy production for some flow rate use wastewater of input UASB (COD $17506 \mathrm{mg} / \mathrm{L}$ ) and output UASB (COD $12272 \mathrm{mg} / \mathrm{L}$ )

\begin{tabular}{|c|c|c|c|c|c|}
\hline \multirow{2}{*}{ No } & \multirow{2}{*}{ Flow } & \multicolumn{2}{|c|}{ Input UASB wastewater } & \multicolumn{2}{c|}{ Output UASB wastewater } \\
\cline { 3 - 6 } & & $\Delta \mathbf{C O D}(\mathbf{m g} / \mathbf{L})$ & $\begin{array}{c}\mathbf{E} \\
\text { (mwatt) }\end{array}$ & $\begin{array}{c}\Delta \mathbf{C O D} \\
\text { (mg/L) }\end{array}$ & $\begin{array}{c}\mathbf{E} \\
\text { (mwatt) }\end{array}$ \\
\hline 1 & 8 & 5659 & 0,082 & 2636 & 0,037 \\
\hline 2 & 9 & 4641 & - & 2526 & - \\
\hline 3 & 10 & 4591 & 0,031 & 2478 & 0,074 \\
\hline 4 & 11 & 3938 & 0,035 & 2629 & 0,086 \\
\hline
\end{tabular}


Also, electricity production is strongly influenced by the type or character of the carbon source. Wastewater with a simple carbon structure (effluent UASB) will produce more energy ( 0.086 watts) even though the COD reduction is only $2629 \mathrm{mg} / \mathrm{L}$. This energy production is different from complex wastewater (input UASB) which only produces 0.035 watts, whereas the COD reduction is greater $(3938 \mathrm{mg} / \mathrm{L})$.

\section{Conclusion}

Microbial fuel cell (MFC) reactors can be made without membranes so that they are cheaper to manufacture. The flow operating system and the multilevel anode-cathode container arrangement will make the ML-MFC reactor effective as an energy producer and wastewater treatment unit. The reactor has been able to produce currents of $0.2 \mathrm{~mA}$ for wastewater before UASB and $0.25 \mathrm{~mA}$ after UASB. Current production is strongly influenced by flow rates, in wastewater with complex pollutant character, an increase in flow rate will decrease current production and the reverse tendency is obtained for wastewater with simple character. The electric power generated for the ML-MFC reactor is 0.035 mwatt for wastewater before UASB and 0.086 mwatt after UASB. The reactor has been able to reduce the COD content by $21 \%$ both for wastewater before UASB and after UASB with a flow rate of $11 \mathrm{~L} / \mathrm{min}$.

This research has been supported by Center of Industrial Pollution Prevention Technology.

\section{References}

[1] D. Fangzhou, X. Beizhen, D. Wenbo, J. Boyang, D. Kun, and L. Hong, Bioresour. Technol., 102, 19, 8914, (2011)

[2] M. R. Khan, M. S. A. Amin, S. Sarker, and K. Ferdaus, J.Chem. Eng., ChE 27, 2, $55,(2012)$

[3] E. L. Bruce, H. Bert, R. Rozendal; S. Uwe, K. Jurg, A. Peter, F. Stefano, W. V. Rabaey, and R. Korneel, Environ. Sci. Technol., 40, 17, 5181, (2006)

[4] E. Baranitharan, M. R. Khan, A. Yousuf, W. Fei, A. Teo, G. Yuan, and A. Tan, FUEL, 143, 72, (2015)

[5] A. E. Ali, O. M. Gomaa, R. Fathey, H. Abd, and E. Kareem, J. Fuel Chem. Technol., 43, 9, 1092, (2015)

[6] J. Sun, W. Li, Y. Li, Y. Hu, and Y. Zhang, Bioresour. Technol., 142, 407, (2013)

[7] D. Permana, H. Putra, and D. Djaenudin. International Journal of Renewable Energy Development, 7(1), 7-12, (2018)

[8] L. M. Tender, C. E. Reimers, H. A. S. Iii, D. E. Holmes, D. R. Bond, D. A. Lowy, K. Pilobello, S. J. Fertig, and D. R. Lovley, Nat. Biotech., 20, 821, (2002)

[9] W. Thung, S. Ong, L. Ho, Y. Wong, F. Ridwan, and Y. Oon, Bioresour. Technol., 197, 284, (2015)

[10] J. Kim, B. Kim, J. An, Y. S. Lee, and I. S. Chang, Bioresour. Technol., 213, 140, (2016)

[11] D. U. Zhuwei, L. I. Qinghai, T. Meng, and L. I. Shaohua, Chinese J. Chem. Eng., 16, 5, 772, (2008)

[12] W. Thung, S. Ong, L. Ho, and Y. Wong, Treatment and electricity generation Pilot 
Scale Single chamber Up-flow Membrane-less Microbial Fuel Cell for Wastewater Treatment and Electricity Generation, in the AIP Conference Proceedings 1828, 020033, (2017) 